\title{
Fetomaternal outcome in pregnancy with oligohydramnios: a prospective study
}

\author{
Heena Talesara*, Vidhi C. Shah, Dipti A. Modi, Rahi S. Modi
}

Department of Obstetrics and Gynecology, Medical College Baroda, S. S. G Hospital, Vadodara, Gujarat, India

Received: 01 December 2020

Revised: 04 January 2021

Accepted: 05 January 2021

\author{
*Correspondence: \\ Dr. Heena Talesara, \\ E-mail: heenatalesara10@gmail.com
}

Copyright: (C) the author(s), publisher and licensee Medip Academy. This is an open-access article distributed under the terms of the Creative Commons Attribution Non-Commercial License, which permits unrestricted non-commercial use, distribution, and reproduction in any medium, provided the original work is properly cited.

\begin{abstract}
Background: Oligohydramnios is defined as amniotic fluid index $<5^{\text {th }}$ percentile or 2 standard deviation below the normal amniotic fluid volume. It affects $4 \%$ of all the pregnancy. The aim of this study is to evaluate the etiological risk factor of oligohydramnios and to assess their clinical significance and mode of delivery and maternal and perinatal outcome.

Methods: This study was conducted at a tertiary health care centre, SSG Hospital, Baroda, from 1st September 2019 to 30th August 2020. It is a prospective study of 200 cases of oligohydramnios with gestational age $>30$ weeks.

Results: The most common risk factor associated with oligohydramnios was hypertensive disorder of pregnancy (35\%) followed by intra uterine growth restriction (31\%), preterm rupture of membranes (17\%), post-datism (5\%) and about $12 \%$ were due to idiopathic causes. Among cases majority were primigravida (43\%). Lower segment caesarean section was done in 86 cases $(43 \%)$, and main indication was fetal distress. There was no maternal mortality in the study. NICU admission for low birth weight (26\%), pre-maturity (20\%), meconium aspiration syndrome (8\%), congenital anomalies (8\%). Among congenital anomalies, posterior urethral valve had highest incidence (50\%) followed by renal agenesis $(25 \%)$. The neonatal mortality was $5 \%$.

Conclusions: Oligohydramnios adversely affects the perinatal outcome. Therefore, it requires meticulous assessment, prompt detection, timely management and treating underlying condition. However, a favourable outcome can be expected by good antenatal and intrapartum surveillance and neonatal care.
\end{abstract}

Keywords: Amniotic fluid index, Congenital anomaly, Fetal distress, Fetal outcome, Lower segment caesarean section, Oligohydramnios

\section{INTRODUCTION}

The role of amniotic fluid is to provide a protective environment for fetal growth. It makes a cushion for the fetus against mechanical and biological injuries. Furthermore, it provides nutrients for the growth and facilitation for movement. ${ }^{1}$

The average amniotic fluid volume in 3rd trimester is 700-800 ml. Clinical assessment of amniotic fluid volume including bimanual palpation, symphysio-fundal height is unreliable. Diagnosis is usually done by ultrasound.
Definition of increased or decreased amniotic fluid volume are based on sonographic criteria. ${ }^{2}$

Oligohydramnios is defined as Amniotic fluid index (AFI) $\leq 5$ (or less than the 5 th percentile) or the absence of a pocket measuring at least $2 \times 1 \mathrm{~cm}^{3}$ It affects $3.9 \%$ of pregnancies between 37 and 40 weeks and $12 \%$ of pregnancies at 41 weeks or later. ${ }^{4-6}$

Usually the degree of Oligohydramnios is proportional to the severity of placental hypoperfusion and IUGR (Intra Uterine Growth Restriction). The most likely cause of 
oligohydramnios in IUGR babies is decreased urine output. $^{7}$

Decreased amount of amniotic fluid, particularly in third trimester, has been associated with multiple fetal risks like cord compression, musculoskeletal abnormalities such as facial distortion and clubfoot, intrauterine growth restriction, low birth weight, fetal distress in labor, meconium aspiration syndrome, severe birth asphyxia, low APGAR scores, NICU admission, congenital abnormities and stillbirths. ${ }^{8}$

Long standing oligohydramnios result in positional deformity resulting from persistent compression by uterine wall. Such deformity includes CTEV (congenital talipes equinovarus), contractures of limbs, wry neck, ankylosis of joints, hip dislocation and Potter's syndrome.

Aim of this study is to evaluate the etiological risk factor of oligohydramnios and to assess their clinical significance and mode of delivery and maternal and perinatal outcome.

\section{METHODS}

This prospective study was conducted over a period of one year from 1st September 2019 to 30th August 2020. All cases coming to labor room with oligohydramnios were included in the study after satisfying inclusion and exclusion criteria.

\section{Inclusion criteria}

In this study all the patients with singleton pregnancy and gestational age of more than 30 weeks were included.

\section{Exclusion criteria}

Women with multiple gestation, with wrong or mistaken dates and gestational age of 30 weeks or less were excluded.

General and systemic examination was performed of all cases.

Obstetric examination included- symphysio-fundal height, presentation and size of baby and fetal heart sound.

Per abdomen and per vaginal examination were done. Baseline investigations were done. Ultrasonography was done to determine gestation age, presentation, placental grading and localization, fetal weight, amniotic fluid index and to detect any major congenital anomalies.

Following observations were recorded- Mode of delivery, indication of caesarean section if performed, perinatal morbidity such as meconium aspiration syndrome, congenital anomalies, hypoglycemia, convulsions and admission to NICU.

\section{Statistical analysis}

This study was designed to record history, duration of pregnancy, per abdominal examination, per vaginal examination, ultrasound findings, progress of labour, mode of delivery, maternal and fetal outcome.

The data was analysed and then presented in simple descriptive statistics using tables after collection. The results were presented as numbers and percentages. The analysed data was compared with different studies and discussed.

\section{RESULTS}

The total number of cases with oligohydramnios included in our study who came to our labor room were 200. Maximum number of cases were in the age group of 2025 years.

Table 1- Distribution according to gravdity.

\begin{tabular}{|lll|}
\hline Gravidity & Number of cases & Percentage \\
\hline Primi gravida & 86 & 43 \\
\hline Multigravida & 114 & 86 \\
\hline Total & 200 & 100 \\
\hline
\end{tabular}

Above table shows, distribution according to gravidity in present study. It shows out of 200 cases, oligohydramnios was seen in primigravida (86) cases, followed by multigravida (114) cases.

Table 2: Causes of oligohydramnios.

\begin{tabular}{|lll|}
\hline Causes & $\begin{array}{l}\text { Number of } \\
\text { cases }\end{array}$ & Percentage \\
\hline $\begin{array}{l}\text { Intra uterine } \\
\text { growth restriction }\end{array}$ & 62 & 31 \\
\hline $\begin{array}{l}\text { Pregnancy induced } \\
\text { hypertension }\end{array}$ & 70 & 35 \\
\hline $\begin{array}{l}\text { Preterm rupture of } \\
\text { membranes }\end{array}$ & 34 & 17 \\
\hline Post datism & 10 & 5 \\
\hline Idiopathic & 24 & 12 \\
\hline Total & 200 & 100 \\
\hline
\end{tabular}

Table 3: Intervensions done in labor room.

\begin{tabular}{|lll|}
\hline Type of intervention & $\begin{array}{l}\text { Number } \\
\text { of cases }\end{array}$ & Percentage \\
\hline Spontaneous labor & 26 & 13 \\
\hline Induction of labor & 88 & 44 \\
\hline $\begin{array}{l}\text { Lower segment } \\
\text { caesarean section }\end{array}$ & 86 & 43 \\
\hline Total & 200 & 100 \\
\hline
\end{tabular}


Above table shows causes of oligohydramnios. Among 200 cases, most common cause of oligohydramnios was pregnancy induced hypertension (70) cases followed by intra uterine growth restriction (62) cases. In 24 cases cause was not found.

Above table shows mode of delivery in cases with oligohydramnios. Out of 200 cases Spontaneous labor was seen in (13\%) 26 cases. lower segment caesarean section was done in (43\%) 86 cases and induction of labor was done in (44\%) 88 cases.

Table 4: Indications of lower segment caesarean section.

\begin{tabular}{|lll|}
\hline Indication & Number of cases & Percentage \\
\hline Elective & 29 & 34 \\
\hline Fetal distress & 32 & 37 \\
\hline $\begin{array}{l}\text { Meconium } \\
\text { stained liquor }\end{array}$ & 13 & 15 \\
\hline $\begin{array}{l}\text { Breech } \\
\text { presentation }\end{array}$ & 5 & 6 \\
\hline $\begin{array}{l}\text { Cephalopelvic } \\
\text { disproportion }\end{array}$ & 7 & 8 \\
\hline Total & 86 & 100 \\
\hline
\end{tabular}

Above table shows indication of lower segment caesarean section. Out of 200 cases, lower segment caesarean section was performed in 86 cases, in which elective lower segment caesarean section was done in (33\%) 29 cases.

Emergency lower segment caesarean section was done in (67\%) 57 cases. Among them, fetal distress was most common indication done in (37\%) 32 cases, followed by meconium stained liquor done in (15\%) 13 cases.

Table 5: Fetal outcome in oligohydramnios.

\begin{tabular}{|lll|}
\hline Fetal outcome & $\begin{array}{l}\text { Number } \\
\text { of cases }\end{array}$ & Percentage \\
\hline $\begin{array}{l}\text { Meconium aspiration } \\
\text { syndrome }\end{array}$ & 16 & $(12)$ \\
\hline Congenital anomaly & 16 & $(12)$ \\
\hline Low birth weight & 52 & $(39)$ \\
\hline Respiratory distress & 40 & $(30)$ \\
\hline Intrauterine fetal death & 10 & $(7)$ \\
\hline Total & 134 & $(100)$ \\
\hline
\end{tabular}

Above table shows fetal outcome in oligohydramnios. Among 200 cases, fetal morbidity was seen in 134 babies $(67 \%)$.

Out of 134 babies intra uterine fetal death was seen in 10 cases. $52(39 \%)$ babies were low birth weight and 40 $(30 \%)$ suffered from respiratory distress. Meconium aspiration was found in (12\%) 16 cases and congenital anomalies also in (12\%) 16 cases.

\section{DISCUSSION}

In present study, 200 cases with oligohydramnios, with gestational age > 30weeks were analysed for maternal and perinatal outcome.

Maximum number of cases (66.9\%) belonged to 20-25 years of age group and result comparable to study done by Ahmar $\mathrm{R}$ et $\mathrm{al}^{9}$ in which mean maternal age was 26.1 years and in study done by Kaur $\mathrm{T}$ et $\mathrm{al}^{10}$ in which it was 25.8 years.

Oligohydramnios was more common in primigravida (43\%) cases which was similar to study done by Bhat et $\mathrm{al}^{11}$ in which $56 \%$ cases were primigravida.

Induction rate in the present study was high (44\%), this is comparable to study done by Casey $\mathrm{B}$ et $\mathrm{al}^{12}$ in which rate of induction of labor was $42 \%$ and in study done by Ahmar $\mathrm{R}$ et $\mathrm{al}^{9}$ in which labour was induced in $42.2 \%$ of cases.

In the present study, fetal distress and meconium stained liquor were the common indications for emergency Lower segment caesarean section in $45 \%$ of cases. Similar observations were made by Umber et $\mathrm{al}^{13}(32 \%)$, Jandial et $\mathrm{al}^{14}(42 \%)$, Nazlima et $\mathrm{al}^{15}(58 \%)$ and in radhamani et $\mathrm{al}^{16}$ it was $31 \%$.

$52 \%$ of the babies were low birth weight compared to $64 \%$ in study done by Bachhav et $\mathrm{al}^{17}$ and $65.3 \%$ in study done by Nazlima et al. ${ }^{15}$

NICU admission was seen in $6.9 \%$ of babies, comparable to study done by Umber et $\mathrm{al}^{13}(8.1 \%)$. Perinatal mortality was $5 \%$ in our study which was similar to study done by Ahmar $\mathrm{R}$ et $\mathrm{al}^{9}(7.7 \%)$, Nazlima et $\mathrm{al}^{15}$ (2.4\%), Radhamani et $\mathrm{al}^{16}(3.07 \%)$.

There was also increase in perinatal morbidity in form of meconium aspiration syndrome (8\%) and congenital anomalies (8\%). Among congenital anomalies, posterior urethral valve had highest incidence $(50 \%)$ followed by renal agenesis $(25 \%)$.

Limitation: In this study $12 \%$ of cases with oligohydramnios were present in which cause was not found. Ultrasound is important tool to diagnose severity of oligohydramnios.

\section{CONCLUSION}

Oligohydramnios is frequent occurrence and demands intensive fetal surveillance and proper antepartum and intrapartum care. Amniotic fluid index is an important component of biophysical profile scoring and its assessment in early third trimester helps to identify women who need more ante partum surveillance so that proper management can be done for the improvement of maternal and perinatal outcome. Due to intrapartum 
complication and high rate of perinatal morbidity and mortality, rates of caesarean section are rising, but decision between vaginal delivery and caesarean should be well balanced so that unnecessary maternal morbidity prevented and other side timely intervention can reduce perinatal morbidity and mortality.

\section{Recommendations}

I would like to express my gratitude to Dr. Dipti A. Modi (Associate professor) of department of Obstetrics and Gynecology, Medical College Baroda, S. S. G Hospital, for her encouragement, valuable suggestions, constant support, all the ways and teaching me to strive for perfection. I also acknowledge my gratitude to my coresidents and all the patients and department of Obstetrics and Gynecology, who have cooperated for the study.

\section{ACKNOWLEDGMENTS}

Authors would like to thank Dr. Nirupam, Dr. Khanna for his support during study.

\section{Funding: No funding sources}

Conflict of interest: None declared

Ethical approval: Not required

\section{REFERENCES}

1. Dashe JS, Bloom SL, Spong CY, Hoffman BL. Williams Obstetrics. New York: McGraw Hill Professional; 2018.

2. James DK, Steer PJ, Weiner CP, Gonik B. High risk pregnancy: management options. $4^{\text {th }}$ ed. $2007: 197-$ 207.

3. Kehl S, Schelkle A, Thomas A, Puhl A, Meqdad K, Tuschy B, et al. Single deepest vertical pocket or amniotic fluid index as evaluation test for predicting adverse pregnancyoutcome (SAFE trial): a multicenter, open-label, randomized controlled trial. Ultrasound Obstet Gynecol. 2016;47(6):674-9.

4. Dashe JS, Bloom SL, Spong CY, Hoffman BL. Williams Obstetrics. New York: McGraw Hill Professional; 2018.

5. Visvalingam G, Purandare $\mathrm{N}$, Cooley S, Roopnarinesingh R, Geary M. Perinatal outcome after ultrasound diagnosis of anhydramnios at term. J Obstet Gynaecol. 2012;32:50-3.

6. Ghimire S, Ghimire A, Chapagain S, Paudel S. Pregnancy outcome in cases of oligo hydramnios after 28 weeks of gestation. Int J Adv Med Health Res. 2016;3:68.

7. Patrelli TS, Gizzo S, Cosmi E, Carpano MG, Di Gangi S, Pedrazzi G, et al. Maternal hydration therapy improves the quantity of amniotic fluid and the pregnancy outcome in third-trimester isolated oligohydramnios: a controlled randomized institutional trial. J Ultrasound Med. 2012;31(2):23944.

8. Sherer DM. A review of amniotic fluid dynamics and the enigma of isolated oligohydramnios. Am J Perinatol. 2002;19:253-66.

9. Ahmar R, Parween S, Kumari S, Kumar M. Neonatal and maternal outcome in oligohydramnios: a prospective study. Int J Contemp Pediatr. 2018; 5:1409-13.

10. Tajinder K, Ruchika S. Feto-maternal outcome in pregnancies with abnormal AFI. IOSR-JDMS. 2016;15(4):71-5.

11. Bhat S, Kulkarni V. Study of effect of oligohydramnios on maternal and fetal outcome. Int J Med and Dent Sci. 2015;4(1):582-8.

12. Casey BM, McIntire DD, Bloom SL, Lucas MJ, Santos R, Twickler DM, et al. Pregnancy outcomes after antepartum diagnosis of oligohydramnios at or beyond 34 weeks of gestation. Am J Obstet Gynecol. 2000;182(4):909-12.

13. Umber A. Perinatal outcome in pregnancies complicated by isolated Oligohydromnios at term. Annals. 2009;15(1):35-7.

14. Jandial C, Gupta S, Sharma S, Gupta M. Perinatal Outcome After Antepartum diagnosis of oligohydromnios at or Beyond 34 weeks of Gestation. JK science. 2007;9(4):213-4.

15. Nazlima N, Fathima B. Oligohydromnios at third trimester and perinatal outcome. Bangladesh J Med sci. 2012;11(1):33-6.

16. Radhamani S, Babitha. A clinical study of fetomaternal outcome in pregnancies with oligohydramnios. Int $\mathbf{J}$ Reprod Contracept Obstet Gynecol. 2017;6:868-71.

17. Bachhav AA, Waiker M. Low amniotic index at term as a predictor of adverse perinatal outcome. J Obstet Gynaecol Ind. 2014;64(2):120-3.

Cite this article as: Talesara $\mathrm{H}$, Shah VC, Modi DA, Modi RS. Fetomaternal outcome in pregnancy with oligohydramnios: a prospective study Int J Reprod Contracept Obstet Gynecol 2021;10:571-4. 